\title{
Morphinofobia: the situation among the general population and health care professionals in North-Eastern Portugal
}

\author{
Henk Verloo*1, Emmanuel K Mpinga2 ${ }^{2}$ Maria Ferreira ${ }^{3}$, Charles-Henri Rapin 4 and Philippe Chastonay ${ }^{5}$
}

\begin{abstract}
Background: Morphinofobia among the general population (GP) and among health care professionals (HP) is not without danger for the patients: it may lead to the inappropriate management of debilitating pain. The aim of our study was to explore among GP and HP the representation and attitudes concerning the use of morphine in health care.

Methods: A cross-sectional study was done among $412 \mathrm{HP}$ (physicians and nurses) of the 4 hospitals and 10 community health centers of Beira Interior (Portugal)and among 193 persons of the GP randomly selected in public places. Opinions were collected through a translated self-administered questionnaire.

Results: A significant difference of opinion exists among GP and HP about the use of morphine. The word morphine first suggests drug to GP $(36,2 \%)$ and analgesia to HP $(32,9 \%$.). The reasons for not using morphine most frequently cited are: for GP morphine use means advanced disease (56\%), risk of addiction (50\%), legal requirements (49,7\%); for HP it means legal risks (56,3\%) and adverse side effects of morphine such as somnolence - sedation $(30,5 \%)$ The sociodemographic situation was correlated with the opinions about the use of morphine.

Conclusions: False beliefs about the use of morphine exist among the studied groups. There seems to be a need for developing information campaigns on pain management and the use of morphine targeting. Better training and more information of HP might also be needed.
\end{abstract}

\section{Background}

During the last decades, considerable progress has been recorded in the knowledge of the action and the use of opiates in pain management [1-3]. In spite of this progress, the pain prevalence in general populations and health care institutions remains high, varying from 20 to $80 \%$ depending on the region or the country [4-7].

Why has this knowledge not been applied by HP and did not have the expected effects among the GP? Do morphine frighten so much the GP and HP becoming a public health problem?

Morphinofobia can be defined as a set of false beliefs concerning the negative effects of morphine in the management of pain [8], an inappropriate attitude of professionals in the pain management due to a lack of

\footnotetext{
* Correspondence: henk.verloo@unil.ch

1 Geneva Altitude Clinic, Montana, Switzerland

Full list of author information is available at the end of the article
}

knowledge [9], a philosophical opposition to the prescription and the use of morphine in pain management [10].

Morphinofobia seems widespread and caused by ignorance, prejudices, false beliefs, economic marketing strategies and limitations in the availability of morphine $[8,10-$ 16].

In 1960, the studies of Robins et al. [17] and Abeles et al. [18] reported false beliefs of health professionals in the use of morphine: it was related to fears of addiction and abuse, to limited information on legal aspects, a lack of knowledge about the use of opiates by health professionals (physicians) and users (patients) and to the negative image of morphine in general. Similar observations have been reported in a recent study by Zacny et al. [19]: morphine was often associated with advanced disease, imminent death, illicit drug addiction, euthanasia, potential risks of abuse, excessive sedation and fear of pursuit by 
authorities [5,7,10,14,20-25]. Few studies compared attitudes and perceptions related to the use of morphine as an analgesic among GP and HP in a given region.

Musi et al. [26] studied the myths of morphine in the Valley of Aosta in Northern Italy interrogating 380 health professionals and the general population about their fears in using morphine. They showed that despite the availability of morphine, its low costs and its efficacy, the prescription and the acceptance of opioides, and more specifically of morphine, in health care institutions was low.

Our study aims to compare morphinofobia among the general population (GP) and health professionals (physicians and nurses) (HP) in a country where the consumption of morphine was multiplied by 4 over the last decade [27], though its prescription is tightly regulated by public health authorities [28].

\section{Methods}

The survey was carried out between August and November 2005 using two structured questionnaires, developed based on the model of Musi et al. [26]. One of the authors (MF) translated the questionnaires in Portuguese and later conducted the survey. After a translation check by two Portuguese health professionals the questionnaires were pilot-tested among $5 \mathrm{GP}$ and $5 \mathrm{HP}$ in the province of Beira Interior.

\section{Data Collection}

The GP was recruited randomly on a given day in two shopping centres, three urban restaurants, the weekly marketplace and at the railroad station of Guarda. The participation criteria were: at least 18 years old, able to answer the questionnaire and living in the region of Beira Interior.

As to the GP, a questionnaire was addressed to $800 \mathrm{HP}$ (nurses and physicians) employed at four hospitals of Beira Interior (hospitals of Cova da Beira, Fundão, Guarda and Castélo Branco) and ten community care centres (Belmonte, Castélo Branco, Covilhã, Fundão, Idanha-A_Nova, Oleiros, Penamacor, Provença-a- Nova, Sertã, Vila Velha of Rodão) with the agreement of the regional Department of Health of Beira Interior.

The HP were working in internal medicine, general surgery, paediatrics, oncology, orthopaedics, emergency and community home care. The participation criteria were: be employed in one of the hospitals or community home care centres for at least a year and having a completed training as a nurse or as a physician.

The questionnaires were distributed via the management of the institutions and answers were returned by the same channel under ceiled envelope. The inquiry was anonymous. The study was approved by the Research
Ethics Committee of the University Institute of Kurt Bösch Sion, Switzerland.

\section{Research Instrument}

For each group, we developed a specific questionnaire based on the study of Musi et al. [26].

The first part of each questionnaire addresses sociodemographic data. The second part of the questionnaire addresses the perception people have of "morphine", its efficacy and its side effects. The questionnaire also explores the attitudes concerning the use of morphine and its acceptance. A judgment scale of 5 levels, ranging from "completely disagree" to "completely agree" was used.

Data was analyzed with " Khi ${ }^{2}$ of Pearson », «t-test for matched samples » and " correlation of Pearson » using the software program SPSS version 15.0. Significant differences ( $p$-value) between categories or groups of variables were defined at $95 \%$.

\section{Results}

The sampling among GP and HP yielded a total of 606 respondents.

\section{Profile of Respondents \\ General population (GP)}

194 persons of GP answered the questionnaire. One questionnaire was discarded. About six out of ten respondents were women. Age range was between 18 and 80 years. About $20 \%$ of the respondents had not been to school and about $30 \%$ had only attended primary school. Almost half of the interviewed people lived in urban areas. A vast majority of respondents (87\%) were Catholics (Table 1). The demographic profile of our so-called GP roughly corresponds to the demographic distribution of the population of the region Beira Interior, except for gender, yet the studied sample must be considered as an opportunistic sample.

\section{Health Professionals (HP)}

Of 700 questionnaires addressed to nurses and 100 to physicians, 412 were returned. The sample included 366 nurses $(89 \%)$ and 46 physicians (11\%). The participation rate of nurses was $52,3 \%$ the physicians' $46,0 \%$. On the average the participation rate was $51,5 \%$. Three quarters of the respondents were women. The average age was 35,5 years. About $70 \%$ of the respondents lived in semiurban areas. The majority of the HP (93\%) were Catholics (Table 1). The sample roughly represents the doctors/ nurses rate in health care in Portugal. Non-respondents were not specifically characterized in our study, but were globally not different from the respondents (same sex ratio, age distribution, religion, and years of professional experience). 
Table 1: Characteristics of the GP and HP

\begin{tabular}{|c|c|c|c|}
\hline Variables & GP n (\%) & HP n (\%) & P-Value \\
\hline \multicolumn{4}{|c|}{ Sex of respondents $(\mathrm{GP} \mathrm{n}=176-\mathrm{HP} \mathrm{P}=412)$} \\
\hline Male & $82(42)$ & $108(26,2)$ & $0,000^{*}$ \\
\hline Female & $111(58)$ & $304(73,8)$ & \\
\hline \multicolumn{4}{|c|}{ Age of respondents (GP $n=174-\mathrm{HP} n=396)$} \\
\hline $18-25$ years & $27(15,5)$ & $82(19,9)$ & \\
\hline $26-65$ years & $102(58,6)$ & $313(76,0)$ & $0,000^{*}$ \\
\hline$>65$ & $44(25,9)$ & $1(0,2)$ & \\
\hline No response & 3 & 16 & \\
\hline \multicolumn{4}{|c|}{ Level of training $(\mathrm{GP} n=176-\mathrm{HPn}=412)$} \\
\hline Without schooling & $36(20,5)$ & & \\
\hline Only primary & $50(28,4)$ & & \\
\hline Secondary school & $46(26,1)$ & & $0,000^{*}$ \\
\hline High school & $20(11,4)$ & $366(88,8)$ & \\
\hline High school & $20(11,4)$ & $366(88,8)$ & \\
\hline University & $24(13,6)$ & $46(11,2)$ & \\
\hline No response & 18 & - & \\
\hline \multicolumn{4}{|c|}{ Place of living (GP $n=176-\mathrm{HP} n=409)$} \\
\hline Rural & $78(44,3)$ & $123(24,4)$ & \\
\hline Urban & $98(55,6)$ & $284(75,6)$ & $0,001^{*}$ \\
\hline Other & - & 5 & \\
\hline No response & 17 & - & \\
\hline \multicolumn{4}{|c|}{ Religion (GP $n=175-\mathrm{HP} n=408)$} \\
\hline Catholic & $152(86,9)$ & $385(93,4)$ & \\
\hline Jewish & $1(0,6)$ & $2(0,5)$ & \\
\hline Jehovah & $22(12,6)$ & $2(0,5)$ & $0,000^{*}$ \\
\hline Protestant & - & $7(1,7)$ & \\
\hline Other & & $16(3,9)$ & \\
\hline No response & 18 & - & \\
\hline
\end{tabular}

* Significant difference P-value $\leq 0.05$

\section{The Myths of Morphine}

\section{Perception of the word "Morphine "}

Significant differences exist between GP and HP in their perception of the word "morphine". For HP the word "morphine" first stands for « analgesic » $(32,9 \%)$, whereas for GP it first means «drugs» $(36,2 \%)$. Other differences exist between GP and HP, such as «medication» $(15,9 \%$ versus 5,2\%,), "sedation- somnolence» $(9,1 \%-0,5 \%)$, «cancer» (0\% versus $14,9 \%)$, «dependency» ( $0 \%$ versus $1,8 \%$, «opiate» (6,9\% versus 15,9\%), «relief» (0\% versus 16,4\%). Some similarities also exist, such as «pain-suffering» (GP
1,7\% versus HP4,1\%) and «end of life - death» ( GP 2,3\% versus HP 2,8\%). One third of GP « does not know » what morphine stands for. The results are summarized in Table 2.

\section{Opinions about the use of morphine as an analgesic}

The opinions among GP and HP concerning the use of morphine as an analgesic appear in Table 3.

GP shows more false beliefs than HP concerning the use of morphine as an analgesic. The largest difference exists for «it means that it is serious» $(46,8 \%$; $\mathrm{p}=0,000)$, 
the smallest for «there is a risk of somnolence or sedation» $(13 \% ; \mathrm{p}=0,002$.)

Relationship between socio- demographic features and the perceptions of the use of morphine as an analgesic

Table 4 presents a matrix of the correlation coefficients of Pearson between socio-demographic features and opinions on the use of morphine as an analgesic.

Data analysis shows an absence of a significant relationship between the sex of the respondents and the questions «risks of delirium» $(\mathrm{r}=0.041 ; \mathrm{p}=0,330)$, «diminish the surviving period» $(\mathrm{r}=0,051 ; \mathrm{p}=0,223)$, «risks of increasing doses» $(\mathrm{r}=0,058 ; \mathrm{p}=0,166)$ and «the legal risks» $(\mathrm{r}=0,025 ; \mathrm{p}=0,543)$. A weak negative relationship was seen between sex and the expressions «it means that it is serious» $(\mathrm{r}=0,134 ; \mathrm{p}=0,001)$, «risks of dependency» $(\mathrm{r}=0,094 ; \mathrm{p}=0,024)$, «risks of somnolence» $(\mathrm{r}=0,110 ; \mathrm{p}=$ $0,008)$ «limited life expectancy» $(\mathrm{r}=0,125 ; \mathrm{p}=0,003)$ and «risks of discrimination» $(\mathrm{r}=0,096 ; \mathrm{p}=0,023)$. Men are less prone to consider and use morphine as an analgesic than women.

A positive weak relationship was observed between the age of the respondents and the perceptions of the use of morphine. The older the respondents, the more false beliefs exist about the use of morphine.
A weak negative relationship between level of training of the respondents and the variable «legal risks» $(\mathrm{r}=$ $0,106 ; \mathrm{p}=0,011)$ was observed. A weak positive relationship was observed between place of living and the expressions «it means that it is serious» $(\mathrm{r}=0,134 ; \mathrm{p}=$ $0,001)$, «risks of dependency» $(\mathrm{r}=0,119 ; \mathrm{p}=0,004)$, «diminish surviving period» $(\mathrm{r}=0,145 ; \mathrm{p}=0,000)$, «limited life expectancy» $(\mathrm{r}=0,147 ; \mathrm{p}=0,000)$ and «risk of discrimination» $(\mathrm{r}=0,169 ; \mathrm{p}=0,000)$. No relationship was noticed with the variables «risk of delirium» $(r=0,053 ; p$ $=0,207)$, «risks of somnolence» $(r=0,025 ; p=0,547)$, «risks of accustom» $(r=0,032 ; \mathrm{p}=0,441)$ and "legal risks» $(\mathrm{r}=0,034 ; \mathrm{p}=0,412)$.

\section{Discussion}

This study compared the use of morphine as perceived by GP and HP in the region of Beira Interior in North-Eastern Portugal. There are differences of perception but also common fears. It might well induce some reluctance regarding the use of morphine. This in turn might influence negatively patient care in general and pain management more specifically.

Most studies reporting "false beliefs" regarding the use of morphine in pain management focus either on specific

Table 2: Perception of the word « morphine » among the GP and HP (only one answer possible)

\begin{tabular}{|c|c|c|c|c|}
\hline GENERAL POPULATION & $n=176(\%)$ & $\begin{array}{l}\text { HEALTH } \\
\text { PROFESSIONELS }\end{array}$ & $n=412(\%)$ & P-VALUE \\
\hline Drug & $63(35,7)$ & Analgesic & $128(32,9)$ & \\
\hline Don't know & $57(32,3)$ & Relief & $64(16,5)$ & \\
\hline Medication & $28(15,9)$ & Opiate & $62(15,9)$ & \\
\hline Sedation- somnolence & $16(9,1)$ & Cancer & $58(14,9)$ & \\
\hline Opiate & $12(6,8)$ & Drug & $43(11,1)$ & \\
\hline Analgesic & $11(6.2)$ & Medication & $20(5,2)$ & $0,000 *$ \\
\hline End-of-Life - Death & $4(2,3)$ & Pain-Suffering & $16(4,1)$ & \\
\hline \multirow[t]{4}{*}{ Pain- Suffering } & $3(1,7)$ & End-of-Live - Death & $11(2,8)$ & \\
\hline & & Dependency & $7(1,8)$ & \\
\hline & & Sedation-Somnolence & $2(0,5)$ & \\
\hline & & No response & 24 & \\
\hline
\end{tabular}

* Significant difference $p$ - value $\leq 0.05$ 
Table 3: Opinions about the use of morphine as an analgesic among the GP and HP

\begin{tabular}{|c|c|c|c|c|}
\hline OPINIONS ABOUT USE OF MORPHINE & GP AGREEMENT (\%) & HP AGREEMENT (\%) & \% DIFFERENCE GP - HP & P-Value \\
\hline $\begin{array}{l}\text { It means that it is serious }(G P n=171 \\
H P n=399)\end{array}$ & $96(56,1)$ & $37(9,3)$ & 46,8 & $0,000 *$ \\
\hline $\begin{array}{l}\text { There is a risk to develop dependency } \\
(\mathrm{GP} n=171 ; \mathrm{HP} n=405)\end{array}$ & $70(41.0)$ & $6(1,5)$ & 39,5 & $0,000 *$ \\
\hline $\begin{array}{l}\text { There is a risk of delirium or euphoria } \\
(\mathrm{GP} n=171 ; \mathrm{HP} n=405)\end{array}$ & $68(39.8)$ & $18(4,4)$ & 35,4 & $0,000 *$ \\
\hline $\begin{array}{l}\text { It does diminish the surviving period } \\
(\mathrm{GP} n=171 ; \mathrm{HP} n=407)\end{array}$ & $61(35,7)$ & $13(3,2)$ & 32,5 & $0,002^{*}$ \\
\hline $\begin{array}{l}\text { There is a risk of somnolence or } \\
\text { sedation }(P G n=170 ; P S n=403)\end{array}$ & $74(43,5)$ & $123(30,5)$ & 13,0 & $0,000 *$ \\
\hline $\begin{array}{l}\text { It can lead to increasing doses } \\
(\mathrm{GP} n=170 ; \mathrm{HP} n=403)\end{array}$ & $85(50,0)$ & $105(26,1)$ & 23,9 & $0,000 *$ \\
\hline $\begin{array}{l}\text { It is a sign of limited life expectancy } \\
(\mathrm{GP} n=171-\mathrm{HP} n=409)\end{array}$ & $47(27,5)$ & $4(1,0)$ & 26,5 & $0,000 *$ \\
\hline $\begin{array}{l}\text { It increases legal risks in relation to } \\
\text { other medication (GP } n=171 ; H P \\
n=407)\end{array}$ & $85(49,7)$ & $229(56,3)$ & $-6,6$ & 0,149 \\
\hline $\begin{array}{l}\text { There is a risk of discrimination } \\
(P G n=169 ; P S n=397)\end{array}$ & $33(19,5)$ & $10(2,5)$ & 17,0 & $0,000 *$ \\
\hline
\end{tabular}

* Significant difference $P$ value $\leq 0.05$

ethnics groups or on health professionals [13,4,29-31]. Studies comparing GP and HP in this field are few. One done by Musi et al. [26] in Northern Italy confirms our results. These authors mention than $39 \%$ of GP primarily associate the word morphine with «drugs» and «the risks of somnolence, dependency and the seriousness of the clinical situation». Other studies also support our observations. Weisse et al. [31] report that the physicians' attitude in prescribing analgesics for pain management varies according sex and ethnic group. Bernades [32] reports a difference in perception of pain according to sex. Riley et al. [29,33] and Robinson et al. [30] show a significant difference in chronic pain management according to age.

In our study morphinofobia among HP seems related to false beliefs on side effects of morphine, risks of addiction and legal constraints in the prescription of morphine. Yet the word morphine is principally associated with the notion of analgesia. Musi et al. [26] reports in his study among HP that the word morphine is associated first with «pain » followed by «analgesia, drug, cancer, death and sedation» which does not differ much from our observations. Other authors report similar data to ours. Seddon et al. [34] mention clearly that the use of morphine in pain management is strongly influenced by the society's perceptions, especially as far as addiction and the legal constrains go. The recent Italian study of Bandieri et al. [13] analysed the consumption of opioids between 2000 and 2008 and showed an increase in the use of opioids in general, but a decrease use of oral morphine. The conclusions of the authors are clear: the behaviour of physicians is still largely contrary to guidelines, suggesting that either cultural or marketing rather than legal factors are mainly responsible for morphinofobia. Staton [35] reports a significant difference in the perception of pain between physicians and patients, especially among certain ethnic groups (Afro-Americans). Nishimori [36] studying opiates abuse among patients at home reported treatment failure by physician in case of opioïde dependency. Ballantyne et al. [37] in a review of literature on 
Table 4: Matrix of the correlation coefficients (Pearson) between the socio-demographics characteristics and the opinions about the use of morphine as an analgesic

\begin{tabular}{|c|c|c|c|c|}
\hline OPINIONS ABOUT USE OF MORPHINE & SEX & AGE & LEVEL OF TRAINING & PLACE OF LIVING \\
\hline Its means that it is serious - Correlation coefficient & $-0.134^{* *}$ & $0.403^{* *}$ & $-0.375^{* *}$ & $-0.134^{* *}$ \\
\hline Sig. (bil.) & 0.001 & 0.000 & 0.000 & 0.001 \\
\hline $\mathrm{N}$ & 570 & 554 & 570 & 568 \\
\hline Risks of developing dependency Correlation coefficient & $-0.094^{*}$ & $0.481^{* *}$ & $-0.545^{* *}$ & $-0.119^{* *}$ \\
\hline Sig. (bil.) & 0.024 & 0.000 & 0.000 & 0.004 \\
\hline $\mathrm{N}$ & 575 & 558 & 575 & 573 \\
\hline Risks of delirium or euphoria - Correlation coefficient & -0.041 & $0.469^{* *}$ & $-0.467^{* *}$ & -0.053 \\
\hline Sig. (bil.) & 0.330 & 0.000 & 0.000 & 0.207 \\
\hline $\mathrm{N}$ & 576 & 559 & 576 & 574 \\
\hline Diminish surviving period - Correlation coefficient & -0.051 & $0.514^{* *}$ & $-0.583^{* *}$ & $-0.145^{* *}$ \\
\hline Sig. (bil.) & 0.223 & 0.000 & 0.000 & 0.000 \\
\hline $\mathrm{N}$ & 578 & 561 & 578 & 576 \\
\hline Risks of somnolence or sedation - Correlation coefficient & $-0.110^{* *}$ & $0.254^{* *}$ & $-0.192^{* *}$ & 0.025 \\
\hline Sig. (bil) & 0.008 & 0.000 & 0.000 & 0.547 \\
\hline $\mathrm{N}$ & 577 & 560 & 577 & 575 \\
\hline Risks of increasing doses - Correlation coefficient & -0.058 & $0.265^{* *}$ & $-0.241^{* *}$ & -0.032 \\
\hline Sig. (bil.) & 0.166 & 0.000 & 0.000 & 0.441 \\
\hline $\mathrm{N}$ & 573 & 556 & 573 & 571 \\
\hline Limited life expectancy - Correlation coefficient & $-0.125^{* *}$ & $0.474^{* *}$ & $-0.488^{* *}$ & $-0.147^{* *}$ \\
\hline Sig. (bil.) & 0.003 & 0.000 & 0.000 & 0.000 \\
\hline $\mathrm{N}$ & 580 & 563 & 580 & 578 \\
\hline Legal constrains- Correlation coefficient & 0.025 & $0.129 * *$ & $-0.106^{*}$ & -0.034 \\
\hline Sig. (bil.) & 0.543 & 0.002 & 0.011 & 0.412 \\
\hline $\mathrm{N}$ & 578 & 561 & 578 & 576 \\
\hline Risks of discrimination - Correlation coefficient & $-0.096^{*}$ & $0.278^{* *}$ & $-0.517^{* *}$ & $-0.169^{* *}$ \\
\hline Sig. (bil.) & 0.023 & 0.000 & 0.000 & 0.000 \\
\hline $\mathrm{N}$ & 566 & 549 & 566 & 564 \\
\hline
\end{tabular}

* Significant correlation on 0,05 level (bilateral)** significant correlation on 0,01 level (bilateral)

chronic pain treatment with opioïdes shows discrimination in prescribing morphine in relation with fears of dependencies.

Many studies report fears and false beliefs concerning the use of morphine in pain management among HP [14,22,38-40]; e.g. Larue et al. [41] report false beliefs of general practitioners and oncologists in France; negative attitudes of nurses in the use of morphine in pain management are reported from Australia [22] from the USA [23] and from Hong Kong [42].

The existence of false beliefs on pain, addiction and abuse of morphine have also been reported by Gilson et al. [21] in a study among 300 American physicians. Furthermore Nwokeji et al. [43] reported that among 267 
general practitioners who agreed to prescribe opioïdes to patients suffering from chronic non-cancerous pains, half feared addiction and abuse. White et al. [44] studying the attitudes of hospital physicians on opiate prescription, confirm that opiophobia is often related to fears of dependency. Devi et al. [45] questioning 253 Malaysian physicians reported that $83 \%$ of the respondents consider a possible addiction and the fear of exceeding sedation and respiratory depression as the main obstacles in prescribing morphine. Clinical documented experiences have proven that these fears are not justified [3,46-49]. Some physicians may also lack knowledge on morphine pharmacokinetics or may be unfamiliar with morphine prescription [50]. Ripamonti et al., [16] concluded in an Italian study of cancer patients that despite the WHO guidelines and EAPC recommendations, there was an inappropriate use of transdermal opioids by Italian physicians in situations where the use of oral morphine was not contraindicated.

Our results showed a rather weak relationship between socio-demographic features and the perceptions of the use of morphine in pain management. Yet morphinofobia was highest among little-educated older men living in rural areas. The cultural and geographic influences on attitudes and beliefs regarding morphine among patients with non cancerous pains have been stressed by Monsivais et al. [51] and Cicero et al. [52]. However a literature review by Turk [53] is cautious in this regard. Ripamonti et al., [16] mentioned that patients were having a problem in taking morphine but they had no cultural problems with other opioids. Most patients knew what morphine meant but do not know the role and the potency of other opioids.

Health professionals play an important role as far as morphinofobia is concerned, be it through a possible lack of knowledge regarding morphine [23,54], be it out of "more philosophical" reasons as suggested by Covington [10] and Bandieri et al., [13]. Yun et al. [55] and Edwards et al. [22] therefore suggest the necessity to develop more positive attitudes among HP regarding the use of morphine.

There are limits to our study. First a generalisation to the population of Beira Interior of our observations might not be indicated because of the small sample of GP and its opportunistic nature. Second, our study focused on attitudes and perceptions on morphine of GP (potential patient) and HP and did not take in consideration the patients' vision. Third, it should be kept in mind that some of our results are matter of debate in the specialized literature [25,52]. Last, our study concentrated on the concept of morphinofobia and should not be generalized for other opioids.

\section{Conclusion}

This study contributes to a better understanding of "the myths of morphine" among the general population and health professionals in the region of Beira Interior. It suggests that efficient pain management is not limited to the prescription of an adequate analgesic according to " the golden standard ». The success of a morphine prescription is influenced by a multitude of other factors.

Our results are in accordance with the results of the study by Musi et al. [26] done in a similar regional setting. There seems to be quite a misunderstanding of "morphine" as well among GP as HP in North-Eastern Portugal. Such a misunderstanding might well end up in straight forward morphinofobia, thus ultimately compromising an appropriate pain management strategy as recommended by W.H.O. guidelines and EAPC recommendations.

This leads us to suggest that there is a need for information campaigns targeting the general population and for better training programs targeting health care professionals based on the theory of planned clinical behaviour [14] in order to improve acceptance and efficacy of pain management.

\section{Competing interests \\ The authors declare that they have no competing interests.}

\section{Authors' contributions}

HV carried out the study concept, drafted the manuscript, the data analysing and interpretation, the follow-up and participated in the questionnaire design and data collection. EKM carried out the design of the questionnaire, the study concept and participated in the draft of the manuscript. MF carried out the design and the translation of the questionnaires, survey and data collection and contributed in the data analysis and interpretation. CHR conceived the study, participated in the questionnaire design, data analysis and interpretation and the draft of the manuscript. PC carried out the draft of the manuscript and participated in the data analysis and interpretation. All the authors approved the final manuscript.

\section{Acknowledgements}

The delay between the survey and this reporting was caused by the absence of financial support and the suddenly death of our dear colleague Prof. C-H Rapin.

The authors thank the hospitals and the community home care centres of Beira Interior for their collaboration.

In memoriam of Professor Charles-Henri Rapin, co-author, who died on the 10th of July 2008 in Sion, Switzerland.

\section{Author Details}

${ }^{1}$ Geneva Altitude Clinic, Montana, Switzerland, ${ }^{2}$ Department of Community health and medicine, Faculty of medicine, University of Geneva, Geneva, Switzerland, ${ }^{3}$ Formerly RN in the hospital Castèlo Branco, Beira Interior,

Portugal and responsible of chirurgical ward hospital of Siders, RSV, Switzerland, ${ }^{4}$ Faculty of Medicine, University of Geneva, Geneva, Switzerland and Director of Department Age, Health, Health and Society, University Institute Kurt Bösch, Sion, Switzerland, and 5Faculty of medicine, University of Geneva, Geneva, Switzerland.

Received: 5 May 2009 Accepted: 22 June 2010

Published: 22 June 2010

\section{References}

1. Apolone G, Bertetto O, Caraceni A, Corli O, de Conno F, Labianca R, Maltoni M, Nicora M, Torri V, Zucco F: Pain in cancer. An outcome 
research project to evaluate the epidemiology, the quality and the effects of pain treatment in cancer patients. Health and quality of Life Outcomes 2006, 4:7

2. Trescot A, Glaser SE, Hansen H, Benyamin R: Effectiveness of opioids in the treatment of chronic non-cancer pain. Pain Physician 2008, 11 (Opioids special issue): $181-200$

3. Trescot AM, Helm S, Hansen H, Benyamin R, Glaser S: Opioids in the management of chronic non-cancer pain: An update of American Society of the international. Pain Physicians (ASIPP) guidelines. Pain Physician 2008, 11(Opioids special issue):11-62.

4. Breivik $\mathrm{H}$ : Survey of chronic pain in Europe, impact on daily life, and treatment. Eur J Pain 2006, 10(4):287-333.

5. Hill CS Jr: The barriers to adequate pain management with opioid analgesics. Seminars in Oncology 1993, 20(2):1-5

6. Salomon L, Tcherny-Lessenot S, Collin E, Coutaux A: Pain prevalence in a French teaching hospital. J Pain Symptom management 2002, 24(6):586-92.

7. Strohbuecker B, Mayer H, Evers GC, Sabatowski R: Pain prevalence in hospitalized patients in a German university teaching hospital. J Pain Symptom management 2005, 29(5):498-506.

8. Tennant F: Overcoming opiophobia and doing opioids right. Pain treatment topics mai 2007 [http://www.pain-topics.org].

9. Elliott TE, Elliot BA: Physician attitudes and about use of morphine for cancer pain. J Pain symptom management 1992, 7(3):141-8.

10. Covington EC: Opiophobia, Opiophilia, Opioagnosia. Pain Medecine 2000, 1(3):217-223.

11. Anthelme J: Au cœur de la souffrance, Histoire de la morphine. Forum de la douleur 2004:1-2.

12. Ballantyne JC: Opioids for chronic pain: Taking stock. Pain 2006, 125:3-4. Editorial

13. Bandieri E, Chirarolanza A, Luppi M, Magrini N, Marata AM, Ripamonti C: Prescribtion op opioids in Italy: everything but the morphine. Annals of Oncology (letters to the editor) 2009, 20:961-2.

14. Godin G, Bélanger-Gravel A, Eccles M, Grimshaw J: Healtcare professionals' intentions and behaviours: A systematic review of studies based on social cognitive theories. BMC Implementation Science 2008, 3(36):1-12.

15. Jacobsen R, Sjoegren P, Moldrup C, Christup L: Physician related barriers to cancer pain management with opioid analgesics: a systematic review. J Opioid Mang 2007, 3(4):207-214.

16. Ripamonti C, Fagnoni E, Campa T, Brunelli C, De Conno F: Is the use of transdermal fentanyl inappropriate to the W.H.O. guidelines and the EAPC recommendations? A study of cancer patients in Italy. Supportive Care in Cancer 2006, 14/5:400-7.

17. Robins LN, Murphy G: Drug use in a normal population of young negro men. Am J Public Health Nations Health 1967, 57(9):1580-1597.

18. Abeles H, Plew R, Laudeutscher I, Rosenthal HM: Multiple-drug addiction in New York City in a selected population group. Public Health Report 1966, 81(8):685-691.

19. Zacny JP, Lichtor S: Nonmedical use of prescription opioids: motive and ubiquity issues. The Journal of Pain 9(6):473-486.

20. Carvalho ML: Especialista em medecina general e familiar. Conhecimentos e atitudes dos médicos em relação ao controlo da dor. Mestrado em Cuidados Paliativos, Faculdade de medecina de Lisboa 2005:179.

21. Gilson AM, Maurer MA, Joranson DE: State Medical Board Members' Beliefs about Pain, Addiction, and Diversion and Abuse: A changing Regulatory Environment. The Journal of Pain 2007, 8(9):682-691.

22. Edwards H, Nash R, Najman J, Yates P, Fentiman BJ: Determinants of nurses intention to administrer opioids for pain relief. Nursing and Health Sciences 2001, 3(3):149-59.

23. McCaffery M, Ferell BR: Opioids and pain management: what do nurses know? Nursing 1999, 29(3):48-52.

24. Musi M: Douleur n'est pas souffrance. Le refus de traitement de la douleur cancéreuse. Mémoire. Master Européen Soins Palliatifs et Thanatologie, Institut Universitaire K Bösch, Sion (CH) 1999:155.

25. Turk DC: Predicting opioid misuse by chronic patients: a systematic review and literature synthesis. Clin J Pain 2008, 24(6):497-508.

26. Musi $M$, Bionaz $A$ : Les mythes de la morphine. Une étude auprès de la population générale, des infirmiers/ères et des médecins en Vallée d'Aoste. Infokara 2003, 4:1-18.
27. International Narcotics Control Bord: United Nations population data 2007. Pain \& Policy Studies Group, University of Wisconsin/WHO collaborating center; 2008

28. Direcção Geral da Saúde: circular normativa n9/DGCG Lisboa. A Dor como $5^{\circ}$ sinal Vital. Ministério da Saude 2003:1-4. Registo sistematico da Intensidade da Dor

29. Riley J, Robinson M, Wade J, Myers C, Price D: Sex differences in negative emotional responses to chronic pain. The journal of Pain 2001 2(6):354-359.

30. Robinson M, Riley J, Myers C, Papas R, Wise E, Waxenberg L, Fillingim R: Gender role expectations of pain: relationship to sex differences in pain. The journal of pain 2001, 2(5):251-257.

31. Weisse C, Sorum P, Dominguez R: The influence of Gender and race on physician pain management decisions. The journal of Pain 2003, 4(9):505-510

32. Bernades S, Keogh E, Lima ML: Bridging the gap between pain en gender research: a selective literature review. Eur J Pain 2008, 12:427-440

33. Riley J, Wade J, Robinson M, Price D: The stages of pain processing across the adult lifespan. The Journal of Pain 2000, 1(2):162-170.

34. Seddon R, Savage MD: Long-term opioid therapy: assessment of consequences and risks. J Pain Symptom management 1996 11(5):274-286

35. Staton LJ: When race matters: disagreement in pain perception between patients and their physicians in primary care. $J$ Nat/Med AssoC 2007, 99(5):532-8.

36. Nishimori M: Successful and unsuccessful outcomes with long-term opioid therapy: a survey of physicians opinions. J Palliat Med 2006, 9(1):50-56.

37. Ballantyne JC, Mao J: Opioid therapy for chronic pain. NEng/ Med J 2003, 349:1943-53.

38. Anderson S, Leikersfeldt G: Management of chronic non-malignant pain. British Journal of Clinical Practice 1996, 50(6):324-329.

39. Correia D, Silva R, Filipe L, Alves E, Freitas D, Ferreira T: The use of opioids in oncologic in madeira island:mythes and difficulties. Sitio web de la sociedad española del dolor 1999:6. SED IV Congreso de la sociedad del dolor (Malaga)

40. Grossman AS: Undertreatement of pain: barriers and remedies. Supportive Care in Cancer 1993, 1(2):74-78.

41. Larue F, Colleau SM, Fontaine A, Brasseur L: Oncologists and primary care physicians' attitudes toward pain control and morphine prescribing in France. Cancer 1995, 76(11):2375-82.

42. Ly L: Knowledge and attitudes regarding pain management among nurses in Hong Kong medical units. J Clin Nurs 2008, 17(15):2014-21.

43. Nwokeji ED, Rascati KL, Brown C, Eisenberg A: Influences of attitudes on Family Physicians Willigness to prescribe Long-acting opioid analgesics for patients with Chronic Nonmalignant Pain. Clinical Therapeutics 2007, 29:2589-2602.

44. Withe ID, Hoskin PJ, Hanks GW, Bliss JM: Analgesics in cancer pain: current practice and belief. Br Journal cancer 1991, 63:271-4.

45. Devi BC, Tangs TS, Corbex M: What doctors know about cancer pain management: an exploratory study in Sarawak, Malaysia. J Pain Palliat Care Pharmacother 2006, 20(2):15-22.

46. Dion $D$, Choinière M: Dépendance et tolérance aux opiacés: des enjeux importants en clinique? Anesthésiologie conférences scientifiques 2004, $3: 1$

47. EPEAC, Quay MC: La morphine et les autres opioïdes dans le traitement de la douleur due au cancer. Br J of Cancer 2001, 84:587-593.

48. Foley KM: Misconceptions and controversies regarding the use of opioids in cancer pain. Anti-cancer drugs 1995, 6(3):4-13.

49. Ripamonti C, De Conno F, Blumhuber H, Ventafridda V: Morphine for relief of cancer pain. The Lancet 1996, 347:1262-1263.

50. Ger LP, Ho ST, Wang JJ: Physicians knowledge and attitudes toward the use of analgesics for cancer pain management: A survey of two medical centres in Taiwan. Journal of Pain and Symptom management 2000, 20(5):335-344

51. Monsivais D, McNeill J: Multicultural influences on Pain Medication attitudes and beliefs in patients with non-malignant chronic pain syndromes. Pain management nursing 2007, 8(2):64-71.

52. Cicero TJ, Suratt H, Inciardi JA, Munoz A: Relationship between therapeutic use of opioid analgesics in rural, suburban, and urban 
locations in the United States. Pharmacoepidemiology and drug safety 2007, 16:827-840

53. Turk DC, Brody MC, Okifuji EA: Physicians attitudes and practices regarding the long-term prescribing of opioids for non-cancer pain. Ann.Intern.Med 1994, 59:201-208.

54. De Conno F, Ripamonti C, Brunelli C: Opioid purchases and expenditure in nine Western European countries:"are we killing morphine? Palliat Med 2005, 19:179-84.

55. Yun YH, Park SM, Lee K, Chang YJ: Predictors of prescription of morphine for severe cancer pain by physicians in Korea. Annual of Oncology 2005, 16:966-971

\section{Pre-publication history}

The pre-publication history for this paper can be accessed here: http://www.biomedcentral.com/1472-684X/9/15/prepub

doi: $10.1186 / 1472-684 X-9-15$

Cite this article as: Verloo et al., Morphinofobia: the situation among the general population and health care professionals in North-Eastern Portugal BMC Palliative Care 2010, 9:15

Submit your next manuscript to BioMed Central and take full advantage of:

- Convenient online submission

- Thorough peer review

- No space constraints or color figure charges

- Immediate publication on acceptance

- Inclusion in PubMed, CAS, Scopus and Google Scholar

- Research which is freely available for redistribution

Submit your manuscript at www.biomedcentral.com/submit
C) Biomed Central 